\title{
A Retrospective Analysis of Patients Receiving Teleradiology Consultations for Computed Tomography in the Emergency Department
}

\author{
Serviste Bilgisayarlı Tomografi için Teleradyoloji Konsültasyonu Yapılan Hastaların \\ Tanımlayıcı Bir Analizi
}

\author{
(D) Kasım Turgut1, (D) ibrahim Hakan Bucak2, (D) Habip Almiş2, (D) Mehmet Şirik33, (D) Mehmet Turgut2 \\ 1Adıyaman University Training and Research Hospital, Department of Emergency Medicine, Adıyaman, Turkey \\ 2Adıyaman University Training and Research Hospital, Department of Pediatrics, Adıyaman, Turkey \\ ${ }^{3}$ Adıyaman University Training and Research Hospital, Department of Radiology, Adıyaman, Turkey
}

\begin{abstract}
Introduction: Teleradiology plays an essential role in the accurate and prompt diagnosis of patients in the emergency department (ED). This study aimed to analyze some factors affecting the use of teleradiology in EDs.

Methods: We retrospectively examined computerized tomography (CT) images taken in our ED over one month. We compared patients for whom emergency physicians (EP) requested an immediate report via teleradiology (group 1), and patients for whom they requested no report and assessed themselves (group 2), in terms of demographic characteristics, complaints, outcomes, and re-admission.
\end{abstract}

Results: The study population consisted of 1999 patients, 831 in group 1, and 1168 in group 2. The patients in group 2 were older $(42.87 \pm 25.12$ years) than those in group $1(38.78 \pm 25.03$ years) $(p<0.01)$. The proportion of reports issued in forensic cases $(85.8 \%)$ was significantly higher than that in non-forensic cases $(p<0.05)$. EPs most commonly requested reports for patients presenting to the hospital due to abdominal pain $(p<0.05)$. EP requested significantly more reports for patients admitted to the hospital and for subjects who died $(p<0.05)$. The re-admission rate among patients who were discharged without teleradiology consultation was higher than the re-admission rate of those who were discharged after the teleradiology consultation ( $p=0.01$ ).

Conclusion: Our findings show that teleradiology is most used in forensic cases, for patients with abdominal pain, who are admitted to clinics, and at after-hours.

Keywords: Emergency, teleradiology, computed tomography, abdominal pain
öZ

Amaç: Teleradyolojinin, acil servislerde hastalara zamanında ve doğru tanı konmasında önemli bir işlevi vardır. Bu çalıșmamızda acil hekiminin teleradyolojiyi daha çok hangi durumlarda kullandığını inceleyerek, acil servislerde teleradyoloji kullanımını etkileyen faktörleri tespit etmek istedik.

Yöntemler: Bir ay boyunca acil servislerde çekilen bilgisayarlı tomografi (BT) görüntülerini retrospektif olarak inceledik. Acil hekiminin teleradyolojiden hemen raporlama istediği (grup 1) ve raporlama istemeyip kendisinin değerledirdiği hastaları (grup 2); demografik özellikleri, şikayetleri, sonlanımları ve tekrar bașvuru açısından karșılaștırdık.

Bulgular: Çalıșmada toplam 1999 hasta olup, bunların 831’i

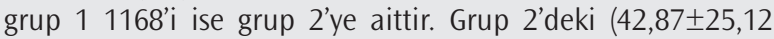
yıl) hastalar grup 1'dekilerden (38,78 $\pm 25,03$ yıl) daha yaşlıdır $(p<0,01)$. Adli olgularda raporlanma oranı $(\% 85,8)$ adli olmayanlara göre anlamlı düzeyde daha yüksektir $(p<0,05)$. Acil hekimleri en fazla raporlamayı karın ağrısı șikayetiyle hastaneye bașvurup abdomen BT çekilen hastalara istemiștir $(p<0,05)$. Acil hekimi hastaneye yatırılan ve ölen olgulara taburcu olanlara göre daha fazla raporlama talep etmiștir $(p<0,05)$. Teleradyoloji konsültasyonu yapılmadan taburcu edilen olguların acile tekrar başvuru oranı, teleradyolojiye konsülte edilip taburcu edilenlerinkinden anlamlı düzeyde daha yüksektir $(p=0,01)$.

Sonuç: Bu araștırmada, adli olgularda, karın ağrılı hastalarda, hastaneye yatırılarak tedavi edilmesi gereken hastalarda ve mesai dışındaki saatlerde acile başvuran hastalarda teleradyolojinin daha fazla kullanıldığını tespit ettik.

Anahtar Kelimeler: Acil, teleradyoloji, bilgisayarlı tomografi, karın ağrısı 


\section{Introduction}

Emergency departments (ED) are units that serve a significant proportion of hospitals' patient populations and that have high mortality rates. In contrast to other fields, the nature of the case that will arrive next is unknown, and a multidisciplinary approach is generally required. It is, therefore, essential for arriving patients to be evaluated in detail and for the necessary tests and consultations to be performed promptly (1). The radiology unit plays a crucial role in early diagnosis and prompt treatment in the management of emergency patients (2). So, the emergency radiology has emerged as a subspecialty in parallel with the development of emergency medicine in recent years. The emergency radiology serves regardless of working hours, but staying in the hospital all the time is difficult for a radiologist. So the online radiology consultation service, known as teleradiology, helps us to solve this problem (3).

Teleradiology refers to the digital transfer of patients' radiological images [computed radiographs (CR), computed tomography (CT) and magnetic resonance imaging (MRI)] to a radiology specialist outside the center where the imaging was performed for consultation or evaluation. The use of teleradiology has spread in parallel to recent advances in picture archiving and communication systems (PACS) (4). The use of teleradiology in EDs is increasing rapidly, and this is making a significant contribution to reducing morbidity and mortality (5). The real increase in the use of teleradiology happened at the beginning of the 2000 s. Between 2003 and 2007, teleradiology use increased from 15\% to $50 \%$ (6). In the USA, teleradiology is used in the majority of imaging reports performed after-hours, and the level of use of teleradiology by radiologists is very high in private hospitals (7).

The teleradiology has been operating in our hospital since 2016. We examined the patients who underwent $\mathrm{CT}$ in our ED and searched for urgent teleradiology consultation demands of emergency physicians (EP). We aimed to determine the factors affecting the use of teleradiology in the ED by evaluating the differences between the patients who got teleradiology consultation urgently and who did not get.

\section{Methods}

\section{Study Design and Population}

This was a retrospective study conducted in the adult ED of a tertiary hospital. Before the study, the approval of the Clinical Research Ethics Committee of Adıyaman University was obtained (decision no: 2019/212). Since it was a retrospective study, no patient consent form was obtained. Our hospital is a tertiary health institution serving a city with a population of 600.000 , and its ED operates by a 24-h shift system, involving four physicians (two emergency medicine specialists and two general practitioners). The hospital administration has contracted with a teleradiology company for evaluating the radiological images (CT and MRI), which were obtained in ED. So, all of the images in our ED have been evaluated by radiologists who were provided by the teleradiology company. Seven radiologists had a minimum of five years of radiology experience in the list of teleradiology company. These radiologists examined the images on a standard monitor in their home. There are radiologists in our hospital during working hours. However, they do not evaluate any radiological images (CR, CT, MRI), which were taken in our ED because of the lack of numbers of radiologists.

Patients presenting with any symptom and undergoing CT scan in the ED of our hospital in January 2019 were included in the study. The records of the patients included were examined retrospectively. We investigated the reason for CT scan, the time performed, whether the EP evaluated the results or requested an emergency report from teleradiology, the time it took to write the report, patients' demographic data, whether the case is forensic and patient outcomes. Legal cases mean events that require prosecution such as traffic accidents, firearm injuries, and stabbings. Then patients were divided into two groups, those for whom emergency teleradiology reports were requested immediately (group 1) and those for whom no teleradiology report was requested (group 2). Differences between the groups were investigated in order to elicit findings concerning teleradiology use in the ED. We also investigated the time taken to write reports and the factors affecting that time in group 1 patients. Additionally, the patients, who were discharged from ED after CT evaluation by EP (without any teleradiology report), were investigated for any re-admission in 24 hours. The cases that have missing data in their medical records were excluded from the study.

\section{System Description and Design}

The CT images in our ED were taken by a Multi-Detector- Row CT scanner (Mx 8000 IDT 16, Philips Medical Systems, Best, The Netherlands). Once radiological imaging has been performed, the images are sent by the technician performing the imaging to the EP and the teleradiology physician via the PACS system in DICOM format. The EP first evaluates them and tries to diagnose. The names of patients whom the physician is unable to diagnose are sent to the remote radiologist using the online messaging service (Skype), together with any preliminary diagnosis. The available radiologist then performs an urgent assessment following receipt of the Skype message from the EP, together with the images that appear on the teleradiology worklist. Once the images have been assessed, the teleradiology physician sends the report with an e-signature back to the emergency system. However, this report is preliminary, and the final report is created in 24 hours after a double-check by a second radiologist. Images for which the EP does not request a report are regarded as routine work, and reports for these are issued within three days at the latest under the contract with the company providing the hospital's teleradiology service. In urgent cases, reports must be issued within 40 min under the contract. The reporting duration in our study was calculated as the time elapsing between the EP sending a Skype ${ }^{R}$ message to the radiologist, and the report appearing on the emergency system.

\section{Statistical Analysis}

Data analysis was performed on Statistical Package for the Social Sciences (SPSS, version 22.0, Chicago, IL, USA) software. $\mathrm{P}<0.05$ was regarded as statistically significant. Data were expressed as mean \pm standard deviation and median values. Student's t-test was used in the analysis of quantitative data when data were normally distributed, and the non-parametric Mann-Whitney $U$ test when data were not normally distributed. The chi-square test and Fisher's exact chi-square test were 
used to compare qualitative data. Correlation between variables was investigated using Spearman's test for nonparametric data and Pearson's test for parametric data.

\section{Results}

During the study period, 2397 images from 1999 patients were evaluated. EPs requested a teleradiology report of 1152 images from 831 patients (group 1), while no emergency reports were sought for 1245 images from 1168 patients, with the EPs evaluating those images themselves (group 2). The mean age of the patients was $41.17 \pm 25.16$ years (range, $0-104$ ), with males comprising 1073 cases and females 926. The mean time to report being issued in group 1 was $35.76 \pm 33.63 \mathrm{~min}$ (range, 2-376), and the majority being issued in 20-39 $\mathrm{min}$ (43.6\%) (Table 1).

Patients in group 1 were significantly younger than those in group 2 $(p<0.01)$. Reports were issued for $40.6 \%$ of female patients, and $42.4 \%$ of males and gender did not affect report request rates $(p>0.05)$. The urgent report rate of forensic cases was $85.8 \%$, compared to $35.3 \%$ for non-forensic cases, and the difference was significant $(p<0.05)$. In terms of outcomes, in group 1, urgent reports were requested for all the patients who died (100\%), for $54.7 \%$ of hospitalized patients, and $39.2 \%$ of discharged patients. In group 2, 60.8\% of cases $(n=1038)$ discharged without teleradiology report, and 35 of these patients re-admitted to our ED within 24 hours, and 15 of them were hospitalized. Nine patients who were discharged after teleradiology reporting also re-admitted to $\mathrm{ED}$, but none of them were hospitalized. The re-admission rate of discharged patients in group 2 (3.4\%) was significantly higher than those in group 1 (1.3\%) ( $p=0.01)$. A significantly higher proportion of urgent report requests were made for hospitalized patients, and patients who died, separately $(p<0.05)$. The majority of imaging $(67.3 \%)$ was performed at after-hours, and urgent report request rate was significantly lower at working hours $(p<0.05)$. The complaint for which urgent reports were most commonly requested was abdominal pain, at $73.7 \%$, while the lowest level of reports was requested for patients presenting due to headache (15.9\%), and a significant relation was determined between complaints of patients and urgent report demand $(p<0.05)$ (Table 2). Time to report delivery was not significantly affected by many variables such as the patient's age and gender, time of imaging, outcomes, and the patient's complaints $(p>0.05)$.

\section{Discussion}

Our findings showed that we made greater teleradiology use in the ED in forensic cases, in patients with abdominal pain, in patients admitted to the clinics, and for images taken at after-hours. Deficiencies in diagnosis occur for such reasons as the large numbers of patients in EDs, the heavy workload, and physicians' lack of attention. As a natural result of this situation, malpractice litigations may be seen. The radiology department provides significant support to EPs in terms of accurate diagnosis, and fewer problems with the diagnosis are observed in EDs in which a radiology specialist is available on a 24-h basis (8). We, therefore, shared the responsibility in our ED by requesting radiologist

\section{Table 1. Descriptive statistics}

\section{Variables}

Gender distribution

Female

Male

Total

\section{Age distribution}

$<18$

$18-44$

45-65

$>65$

Region of body

Head

Cervical

Thorax

Abdomen

Pelvis

Extremity

Total number of films

Turnaround time (minutes)

$<20$

20-39

40-59

$>60$

\section{Urgently reported}

n (\%)

$376(40.6 \%)$
$455(42.4 \%)$
$831(41.6 \%)$

$172(46.6 \%)$

$336(44.6 \%)$

$168(36.6 \%)$

$155(37.1 \%)$

$419(32.8 \%)$

$102(80.9 \%)$

$213(56.6 \%)$

$391(74.5 \%)$

$11(50 \%)$

16 (22.2\%)

$1152(48.1 \%)$

\section{Routinely reported}

n (\%)

Total

$550(59.4 \%) \quad 926$

$618(57.6 \%) \quad 1073$

$1168(58.4 \%) \quad 1999$

$197(53.4 \%) \quad 369$

\begin{tabular}{|l|l|}
$417(55.4 \%)$ & 753
\end{tabular}

$291(63.4 \%) \quad 459$

\begin{tabular}{l|l}
$263(62.9 \%)$ & 418
\end{tabular}

\begin{tabular}{l|l}
\hline $857(67.2 \%)$ & 1276
\end{tabular}

\begin{tabular}{|l|l|}
\hline $24(19.1 \%)$ & 126 \\
\hline
\end{tabular}

$163(43.4 \%) \quad 376$

$134(25.5 \%) \quad 525$

$11(50 \%)$

$56(77.8 \%)$

1245 (51.9\%)

72

2397

N/A

231

N/A

362

N/A

132

1274 
Table 2. Comparison of factors that affect the reporting

\begin{tabular}{|c|c|c|c|}
\hline Variables & Urgently reported & Routinely reported & $\mathbf{p}$ \\
\hline Age & $38.78 \pm 25.03$ & $42.87 \pm 25.12$ & $<0.001$ \\
\hline \multicolumn{4}{|l|}{ Gender } \\
\hline Female & $376(40.6 \%)$ & $550(59.4 \%)$ & 0.416 \\
\hline Male & $455(42.4 \%)$ & $618(57.6 \%)$ & - \\
\hline \multicolumn{4}{|l|}{ Forensic case } \\
\hline Yes & $212(85.8 \%)$ & $35(14.2 \%)$ & $<0.001$ \\
\hline No & $619(35.3 \%)$ & $1133(64.7 \%)$ & - \\
\hline \multicolumn{4}{|l|}{ Outcome of patient } \\
\hline Exitus & $4(100 \%)$ & $\mathrm{N} / \mathrm{A}$ & $<0.001$ \\
\hline Hospitalized & $157(54.7 \%)$ & $130(45.3 \%)$ & - \\
\hline Discharged & $670(39.2 \%)$ & $1038(60.8 \%)$ & - \\
\hline \multicolumn{4}{|c|}{ Readmission of discharged patients } \\
\hline Yes & $9(20.5 \%)$ & $35(79.5 \%)$ & 0.01 \\
\hline No & $661(39.7 \%)$ & $1003(60.3 \%)$ & - \\
\hline \multicolumn{4}{|l|}{ Period of filming } \\
\hline 08:01-16:00 & $222(33.9 \%)$ & $432(67.1 \%)$ & $<0.001$ \\
\hline 16:01-08:00 & $609(45.3 \%)$ & $736(54.7 \%)$ & - \\
\hline \multicolumn{4}{|l|}{ Complaints patient } \\
\hline Trauma & $330(44 \%)$ & $420(56 \%)$ & $<0.001$ \\
\hline Headache & $74(15.9 \%)$ & 391 (84.1\%) & - \\
\hline Chest pain & $22(38.6 \%)$ & $35(61.4 \%)$ & - \\
\hline Abdominal pain & $272(73.7 \%)$ & $97(26.3 \%)$ & - \\
\hline Dyspnea & $59(45.4 \%)$ & $71(54.6 \%)$ & - \\
\hline Cognitive problems & $74(32.5 \%)$ & $154(67.5 \%)$ & - \\
\hline
\end{tabular}

reports to protect our own against malpractice litigations in cases the EP was unable to diagnose, and especially in forensic cases.

Studies have listed trauma, abdominal pain, and respiratory problems as the most common causes of presentations to the ED (9). Among these cases, patients with abdominal pain have a high possibility of misdiagnosis by EP. The cause of abdominal pain may sometimes not be identified, despite the use of assistant diagnostic tools such as CT (10). Nonetheless, the importance of $C T$ in patients with abdominal pain should not be underestimated. Studies have reported that CT resulted in a modification of treatment in $42 \%$ of patients with abdominal pain, that it usually results in the administration of surgical treatment on time, and that it reduces repeated presentations to the $\operatorname{ED}(11,12)$. One study examining the increasing use of tomography revealed that the highest increase in requests in 1996-2007 was for abdominal CT, involving a 10fold rise (13). However, another study also observed that EPs incorrectly evaluated radiological images and abdominal CT significantly more than radiologists $(14,15)$. Moreover, the most significant discrepancy with images evaluated by radiologists was seen in tomographies of the neck and abdomen (16). So, the EP must receive support from a radiologist physician when evaluating abdominal CT (17). Another study showed that EPs evaluated cranial CTs to the same extent as radiologists (18). In our study, the patients with non-traumatic abdominal pain were the group for which CT reports were most frequently issued. Subjects with non-traumatic headache were the group with the lowest rate of CT reports. This shows that the condition in which EPs have the most significant difficulty evaluating and for which they most need to consult the teleradiology unit is abdominal pain, while they are better able to interpret cranial CT findings.

In recent years, an increasing number of advanced radiological tests have been used in the USA. However, this has not, in turn, increased emergency pathological diagnoses, and therefore hospitalization rates. Despite many endeavors to make less use of CT, EPs still insist on using the technique, either to avoid malpractice litigation or else because it is a readily available and rapid diagnostic guide $(19,20)$. Also, the use of CT appears to significantly reduce waiting times in the ED among patients requiring to be admitted for treatment in clinics (21). In our study, 85.4\% of patients undergoing radiological imaging were discharged. Moreover, non-report rates among discharged patients (60.8\%) are also both high. The re-admission rate among these patients was 3.4\%, and $42.9 \%$ of these re-admissions were hospitalized. So, EPs should avoid discharge of patients without teleradiology reports.

Presentations to the ED occurred after 17:00 $\mathrm{h}$ in $62.8 \%$ of adults and $72.5 \%$ of children in one study (22). Another study reporting that $59.5 \%$ of patients arrived at after-hours determined a rate of CT of $54.5 \%$ within that time frame (21). The primary aim behind the teleradiology use is 
to support EPs in terms of diagnosis after-hours (7). The vast majority of our patients admitted to ED at after-hours, and the count of patients in which urgent report was requested after-hours was higher than those of at working hours. We have access to the teleradiology 24-h of day.

The principal contribution of the radiologist to the ED and patient care consists of imaging reports issued promptly and accurately. These reports prevent time loss of patients in the ED and unnecessary crowding (23). One study comparing teleradiology with radiological opinions by telephone showed that in the event of teleradiology being used, the time between imaging being performed and a report issued was less than $34 \mathrm{~min}$ (24). Agrawal et al. (25) reported a time of $34.03 \mathrm{~min}$, and Shah et al. (16) of $28.46 \pm 9.20 \mathrm{~min}$. In our study, we calculated a time of $35.76 \pm 33.63 \mathrm{~min}$ and the expected time (<40 $\mathrm{min}$ ) was maintained in $71.4 \%$ of the cases.

CT use in ED increases with patient age. Patients aged over 65 constituted the group in which CT was most performed (26.7\%), with the lowest rate of CT being observed in patients under nine (3\%). This was attributed to chronic diseases increasing with age and to sensitivity over radiation exposure in children. In the same study, it was found that more CTs were scanned on female patients (20). In our study, CT was taken mostly in the 18-44 age group (37.7\%), and for male patients. Trauma was the most common cause of presentation in our cases. We attributed this to traumas being particularly common in young men with active lifestyles.

\section{Study Limitations}

The main limitation in this study is that the patients whose radiological images were evaluated by EPs and discharged from the hospital were not analyzed for any discrepancy between the radiology interpretation performed by the EP and the radiologist. Because this paper is not a consistency study, and instead of that, we searched the records of these patients for any re-admission and hospitalization.

\section{Conclusion}

Our study findings identified forensic cases, patients presenting with non-traumatic abdominal pain, patients requiring admission to clinics, and presentations at after-hours as the factors affecting the teleradiology use in the ED. EPs should demand teleradiology reports for all images to avoid re-admissions. We think that teleradiology services are beneficial for EPs and should become more prevalent in competing with crowds in EDs worldwide.

Ethics Committee Approval: Before the study, the approval of the Clinical Research Ethics Committee of Adıyaman University was obtained (decision no: 2019/2-12).

Informed Consent: Since it was a retrospective study, no patient consent form was obtained.

Peer-review: Externally peer-reviewed.

Author Contributions: Concept - K.T.; Design - K.T., İ.H.B.; Supervision - M.S., M.T.; Resources - H.A.; Data Collection and/or Processing - H.A., K.T.; Analysis and/or Interpretation - M.S.,H.A.; Literature Search - K.T.; Writing Manuscript - K.T., I.H.B.; Critical Review - M.T., M.Ş.
Conflict of Interest: No conflict of interest was declared by the authors.

Financial Disclosure: The authors declared that this study received no financial support.

\section{References}

1. Cıkrıklar HI, Yurumez Y, Keles I, Ozdinc S, Selvi F, Engindeniz Z, et al. Emergency room consultations: Problems and solutions. Eurasian J Emerg Med 2015; 14: 167-71

2. Wagner MG, Fischer MR, Scaglione M, Linsenmaier U, Schueller G, Berger FH, et al. Subspecialisation in emergency radiology: Proposal for a harmonised European curriculum. GMS J Med Educ 2017; 34: Doc61.

3. Choy G, Novelline RA. Past, present, and future of emergency radiology. Can Assoc Radiol J 2013; 64: 85-9.

4. European Society of Radiology (ESR). ESR teleradiology survey: results. Insights Imaging 2016; 7: 463-79.

5. du Toit M, Malau-Aduli B, Vangaveti V, Sabesan S, Ray RA. Use of telehealth in the management of non-critical emergencies in rural or remote emergency departments: A systematic review. J Telemed Telecare 2019; 25: 3-16.

6. Sıkka N, Paradise S, Shu M. ACEP Emergency telemedicine section. Telehealth in Emergency Medicine: A Primer. Telemedicine Primer 2014.

7. Platts-Mills TF, Hendey GW, Ferguson B. Teleradiology interpretations of emergency department computed tomography scans. J Emerg Med 2010; 38: 188-95.

8. Moonen PJ, Mercelina L, Boer W, Fret T. Diagnostic error in the Emergency Department: Follow up of patients with minor trauma in the outpatient clinic. Scand J Trauma Resusc Emerg Med 2017; 25: 13.

9. Thijssen WA, van Mierlo E, Willekens M, Rebel J, Sandel MH, Giesen P, et al. Complaints and diagnoses of emergency department patients in the Netherlands: A comparative study of integrated primary and emergency care. PloS One 2015; 10: e0129739.

10. Macaluso CR, McNamara RM. Evaluation and management of acute abdominal pain in the emergency department. Int J Gen Med 2012; 5: 789-97.

11. Barksdale AN, Hackman JL, Gaddis M, Gratton MC. Diagnosis and disposition are changed when board-certified emergency physicians use CT for nontraumatic abdominal pain. Am J Emerg Med 2015; 33: 1646-50.

12. Pandharipande PV, Reisner AT, Binder WD, Zaheer A, Gunn ML, Linnau KF, et al. CT in the Emergency Department: A real-time study of changes in physician decision making. Radiology 2016; 278: 812-21.

13. Kocher KE, Meurer WJ, Fazel R, Scott PA, Krumholz HM, Nallamothu BK. National trends in use of computed tomography in the emergency department. Ann Emerg Med 2011; 58: 452-62.

14. Benger JR, Lyburn ID. What is the effect of reporting all emergency department department radiographs? Emerg Med J 2003; 20: 40-3.

15. Kang MJ, Sim MS, Shin TG, Jo IJ, Song HG, Song KJ, et al. Evaluating the Accuracy of Emergency Medicine Resident interpretations of abdominal CTs in patients with non-traumatic abdominal pain. J Korean Med Sci. 2012; 27: 1255-60.

16. Shah NA, Hoch M, Willis A, Betts B, Patel HK, Hershey BL. Correlation among on-call resident study volume, discrepancy rate, and turnaround time. Acad Radiol 2010; 17: 1190-4.

17. Bagheri-Hariri S, Ayoobi-Yazdi N, Afkar M, Farahmand S, Arbab M, Shahlafar $\mathrm{N}$, et al. Abdominal and pelvic CT scan interpretation of emergency medicine physicians compared with radiologists' report and its impact on patients' outcome. Emerg Radiol 2017; 24: 675-80.

18. Ardic S, Guneysel O. Emergency medicine residents can assess cranial computed tomography scans consistently with radiologists. Journal of Acute Medicine 2015; 5: 92-5. 
19. Dick EA, Varma D, Kashef E, Curtis J. Use of advanced imaging techniques during visits to emergency departments-implications, costs, patient benefits/ risks. Br J Radiol 2016; 89: 20150819.

20. Kirsch TD, Hsieh YH, Horana L, Holtzclaw SG, Silverman M, Chanmugam A. Computed tomography scan utilization in emergency departments: a multistate analysis. J Emerg Med 2011; 41: 302-9.

21. Li CJ, Syue YJ, Lin YR, Cheng HH, Cheng FJ, Tsai TC, et al. Influence of CT utilisation on patient flow in the emergency department: a retrospective 1-year cohort study. BMJ Open 2016; 6: e010815.

22. Pitts SR, Niska RW, Xu J, Burt CW. National Hospital Ambulatory Medical Care Survey: 2006 emergency department summary. Natl Health Stat Report 2008; $1-38$.
23. Towbin AJ, Iyer SB, Brown J, Varadarajan K, Perry LA, Larson DB. Practice policy and qualityinitiatives: decreasing variability in turnaround time for radiographicstudies from the emergency department. Radiographics 2013; 33: 361-71.

24. Martinon A, LePogam MA, Boublay N, Ganne C, BenCheikh A, Buron C, et al. Teleradiology saves times in cases of vital emergencies: Acomparative study with on-call radiology in two urban medium-sized French hospitals. European Research in Telemedicine 2014; 3: 151-60.

25. Agrawal A, Koundinya DB, Raju JS, Agrawal A, Kalyanpur A. Utility of contemporaneous dual read in the setting of emergency teleradiology reporting. Emerg Radiol 2017; 24: 157-64. 